\title{
Health Capital as a Strategic Component of Russian Economic Security
}

Ishmuratov R.R.

Kazan Federal University, Institute of Management, Economics and Finance, Kazan, 420008, Russia

Malganova I.G.

Kazan Federal University, Institute of Management, Economics and Finance, Kazan, 420008, Russia

Email: irigrimmm@gmail.com

Gallyamova D.Kh.

Kazan Federal University, Institute of Management, Economics and Finance, Kazan, 420008, Russia

Pratchenko O.V.

Kazan Federal University, Institute of Language, 420008, Kazan, Russia

\section{Doi:10.5901/mjss.2014.v5n28p22}

\section{Abstract}

The paper presents the theoretical and methodological aspects of health capital formation as a component of economic security of the territory. The tendencies of health capital development in connection with social and economic trends of modern Russian development are analyzed. The authors offer some ways of improving the methodological approach, namely application of Keynes's concept of uncertainty about the economic future. The formula of calculation of health potential depending on a number of factors, determining the character of health capital consumption, is suggested.

Keywords: region, economic security, human assets, health capital, institutional changes, lifespan, territorial development

\section{Introduction}

Analysis of publications devoted to the problems of economic security allows to identify the following spheres of security: government activity aimed at the ability of the economy for growth, financial, scientific-technical, investment, foreign trade, industrial, demographic, social.

Concerning the definition of economic security a number of scientists focus attention on the social component: protection of the vital interests of person, society and state [8].

In the current work, the authors set the task to study the essence of health capital, to consider it as a part of the economic security of the state (territory) on specific examples and figures.

In the economic literature the economic development is associated with the optimal use of available resources. In this sense a person, the level his development and human potential is one of the most important resources. In 1990, the United Nations Development Programme introduced to the concept of human development index (HDI) [1] .This integral index, which is calculated annually for comparison of different countries on the basis on three equally important components (standard of living, of literacy and education, of life expectancy), as the main characteristics of the sphere of human potential under study.

Beginning with the report of 2013 , this ranking is implemented in the following way: the full list of national economies, on which the assessment was implemented, is made; the list is grouped in the descending order of HDI, serial numbers are assigned according to national economies (in 2013 these were the numbers from 1 to 186), then the quartiles are allocated according to these numbers. Thus, in 2013 the countries with atomic numbers from 1 to 47 were assigned to the first group with "very high" index; numbers from 48 to 94 - to the second group with "high" index; from 95 to 141 - to the third group with "average" index; from 142 to 186 - to the fourth group with "low" index. The Russian Federation is in the second group [1]. 


\section{Method}

The content of the HDI indicators suggests their use on the macro level. On the regional level, where the production process is more specific, the necessity of detailed indicators of human potential arises because of their use in practice in order to obtain better results. For example, the indicator "life expectancy" requires additional data on factors which increase or decrease longevity, which finally reflect human health. In some cases such notions as "human capital" and "health capital" that characterize human activity in a different aspect, are used. If the concept "human capital" is a quite common term and is means one of the types of production factors, the concept "health capital" has not accepted common meaning yet.

Some authors identify this notion with the notion "human capital", or give other different meanings $[6,8,10]$. At the same time, these authors take the statements on "health capital" in the work of Grossman as the starting position of their research [2]. In his work, the definitions and concepts of "human capital" and "health capital" are given. The main idea of Grossman is that health can be considered as some durable product which is necessary for production of human capital. And health has a dual nature and can be considered as: a) consumer amenities; b) means for profit earning. Exactly in its second function it presents a component of the human capital; it is the object of investments. In this case, health and medicine are the sectors producing "health capital." Grossman gives health as durable product the ability to accumulate health potential within the frames of human capital. Such approach to economic category "health capital" allows to expand the field of research. So, Rozmainsky [3] revealed additional features of health capital. First, he noted the low life expectancy in Russia in comparison with the developed countries (Table 1).

Table 1: Average expected lifespan of population in 2011

\begin{tabular}{|l|c|c|c|c|}
\hline \multirow{2}{*}{ Countries } & \multicolumn{3}{|c|}{ Average expected lifespan, years } & \multirow{2}{*}{ Difference between Men and Women } \\
\cline { 2 - 4 } & Men (M) & Women $(\mathrm{W})$ & National average & 8,1 \\
\hline Japan & 78,0 & 86,1 & 82,6 & 4,3 \\
\hline Sweden & 78,7 & 83,0 & 80,9 & 5,6 \\
\hline Germany & 76,5 & 82,1 & 79,4 & 5,2 \\
\hline USA & 75,6 & 80,8 & 78,3 & 3,5 \\
\hline China & 71,3 & 74,8 & 73,0 & 9,8 \\
\hline Russia & 65,5 & 75,3 & 70,3 & 6,8 \\
\hline Honduras & 66,9 & 73,7 & 70,2 & $-1,5$ \\
\hline Zimbabwe & 44,1 & 42,6 & 43,5 & \\
\hline
\end{tabular}

Rozmainsky explained such phenomenon by the fact that the Russians have losses of health capital due to significant uncertainty of future. Unbelief in future does not allow people to be seriously engaged with their health which is the basis of health capital. According to Lomonosov, "... preservation and multiplication of the Russian people is the main aim of the state; it is the majesty, power and wealth of the country; and deliverance of the people from death" [3]. In this sense, the life expectancy is one of the key indicators of health capital.

According to Rozmainsky, the uncertainty of future is caused by the type of capitalism that replaced the administrative-economic system. It's about the family and crony capitalism which is very different from the existing capitalism in developed countries. According to Rozmainsky, uncertainty in future pushes the Russian to shopthermizm and investment myopia, provokes alcoholism and drug addiction. One cannot deny that. At the same time, some refinements are required. Following Keynes, representatives of the post-Keynesian tradition put the problem of the ontological uncertainty of future which implies a fundamental lack of knowledge about what has not happened yet, into the center. This problem becomes important in connection with the fact that when it is impossible to give any exact quantitative estimate, it is still necessary to take a decision, and it is irreversible. That is why, uncertainty about the future, necessity to take decisions and their irreversibility are the triune problem which economic agents face with.

Thus, the future is fundamentally uncertain - "uncertainty of future" is inherent to any kind of capitalism, and not only capitalism. According to the authors, the uncertainty of future in Russia is caused by the fact that Russia is a country rich in natural resources. As practice shows, these countries fall into the " staple trap" and transform the industrial structure in the direction of predominance of the extractive industries. At that democratic institutions close up, corruption increases, quality of legislation stagnates, and so on. G. Then the possibility of misappropriation of raw materials appears. And the so-called "small groups" take this opportunity. Mansur Olson says: "... small groups of special interests will provide their members by collective goods more effectively and will successfully lobby their interests in the 
government, despite the fact that these interests often contradict the interests of the society" [4]. In our opinion, these problems should be solved by democratic institutions within the frames of self-development of the economic system.

According to the study results of the World Bank, the assessment of quality of institutions in hydrocarbon-rich countries was significantly lower than the average indicators in the countries with emerging transition economy and developed countries [5]. Countries with a low level of development of institutions fall into a vicious circle - "trap of development"; underdevelopment of institutions leads to a lack of incentives and to their improvement (table 2).

Table 2: Assessment of quality of institutions by countries, 2011

\begin{tabular}{|l|c|c|c|c|c|c|}
\hline Countries & $\begin{array}{c}\text { Publicity and } \\
\text { reporting }\end{array}$ & $\begin{array}{c}\text { Political } \\
\text { stability }\end{array}$ & $\begin{array}{c}\text { Efficiency of } \\
\text { government } \\
\text { performance }\end{array}$ & $\begin{array}{c}\text { Quality of } \\
\text { legislation }\end{array}$ & $\begin{array}{c}\text { Level of } \\
\text { supremacy of } \\
\text { laws }\end{array}$ & $\begin{array}{c}\text { Level of } \\
\text { corruption }\end{array}$ \\
\hline 1.Sweden & 1,53 & 1,13 & 1,99 & 1,68 & 1,90 & 2,24 \\
\hline 2.Finland & 1,48 & 1,36 & 1,95 & 1,58 & 1,87 & 2,34 \\
\hline 3.USA & 1,12 & 0,59 & 1,65 & 1,58 & 1,65 & 1,55 \\
\hline 4. Taiwan & 0,70 & 0,72 & 0,88 & 1,07 & 0,77 & 0,55 \\
\hline 5. South Korea & 0,59 & 0,41 & 1,26 & 0,73 & 0,79 & 0,45 \\
\hline 6. Ukraine & $-0,03$ & $-0,01$ & $-0,60$ & $-0,39$ & $-0,62$ & $-0,72$ \\
\hline 7.Russia & $-0,97$ & $-0,62$ & $-0,32$ & $-0,56$ & $-0,91$ & $-0,98$ \\
\hline 8.Tadjikistan & $-1,32$ & $-0,74$ & $-0,88$ & $-0,97$ & $-1,12$ & $-0,99$ \\
\hline
\end{tabular}

According to Friedrich List, the wealth of the nation is not the productive forces, but the ability of nation to use them. In other words, the institutions in a certain structure have a decisive influence on the effectiveness and efficiency of the economy in the operation of the national economy.

More advanced institutions in developed countries contribute the more adequate overcoming of fundamental uncertainty of the future, which cannot be said about the condition of public institutions in Russia. Thus, the low level of the institutions affects the level of spending on health support on the part of individuals, as well as of the state (Table 3).

Table 3: Health spending by years

\begin{tabular}{|c|c|c|c|c|c|}
\hline \multirow[b]{2}{*}{ Country } & \multirow[b]{2}{*}{$\begin{array}{l}\text { Average national life } \\
\text { expectancy (2011), years }\end{array}$} & \multicolumn{2}{|c|}{$\begin{array}{l}\text { Total costs on public health } \\
\text { service }\end{array}$} & \multicolumn{2}{|c|}{ Public expenditures on public health service } \\
\hline & & $\begin{array}{c}\% \\
\text { GDP } \\
(2009)\end{array}$ & $\begin{array}{l}\text { Per capita, in dollars by } \\
\text { PPP (2009) }\end{array}$ & $\begin{array}{l}\text { in \% from all public } \\
\text { expenditures (2009) }\end{array}$ & $\begin{array}{c}\text { Per capita, in dollars by } \\
\text { PPP (2009) }\end{array}$ \\
\hline Russia & 70,3 & 5,6 & 1043,0 & 63,4 & 661,0 \\
\hline Germany & 79,4 & 11,7 & 4219,0 & 76,9 & 3243,0 \\
\hline Sweden & 80,9 & 10,0 & 3722,0 & 81,5 & 3033,0 \\
\hline Japan & 82,6 & 9,5 & 3045,0 & 82,3 & 2507,0 \\
\hline USA & 78,3 & 18,0 & 7960,0 & 48,0 & 3795,0 \\
\hline World in average & - & 9,4 & 990,0 & 59,1 & 584,0 \\
\hline
\end{tabular}

As we can see from the table, the expenditures for health care in developed countries exceed the expenditures in Russia in 3-4 times.

In modern conditions, health is not just value, it is becoming a commodity, on the quality of which the welfare of the family and the state depends. Indicators characterizing the level of public health, such as life expectancy, mortality of population of working age, disease incidence of children and adolescents, cause concern for the future of our country.

Mental and physiological types of health workforce are essential for economic security in the context of social indicators. The quality of human capital, in particular, determines the productivity and competitiveness of the economy of the region as a whole. "Meanwhile, the living conditions of man become very complicated. Neuropsychiatric work loads increase under the influence of the growing rhythm and tension of modern production. All this leads to the increase of depression and different emotional stresses. Neutralization of these stresses depends on the fact, how well the social sphere of the region functions. That is why the level of suicide can be one of the safety criteria of functioning of institutions of the social sphere. The World Health Organization identifies the level of 13 suicides per 100,000 of population of the territory as a critical one [7] (see Table 4). 
Table 4: Dynamics of the suicide level of countries (people, for 100000 people)

\begin{tabular}{|l|c|c|c|c|c|c|c|}
\hline Country & 1980 & 1985 & 1990 & 1995 & 2000 & 2005 & 2011 \\
\hline 1. Russia & 34,6 & 31,2 & 26,5 & 41,5 & 39,4 & 32,2 & 21,4 \\
\hline 2. Japan & 17,6 & 19,4 & 16,3 & 17,2 & 24,1 & 24,2 & 23,8 \\
\hline 3. USA & 11,8 & 12,3 & 12,4 & 11,9 & 10,4 & 11,0 & $11,8(2008)$ \\
\hline 4. Germany & n.d. & n.d. & 17,8 & 15,8 & 13,5 & 13,0 & $9,5(2009)$ \\
\hline 5. Great Britain & 8,8 & 9,0 & 8,1 & 7,4 & 7,5 & 6,7 & $6,9(2009)$ \\
\hline 6. Norway & 12,4 & 14,1 & 15,5 & 12,6 & 12,1 & 11,5 & $11,9(2009)$ \\
\hline 7. China & n.d. & 17,6 & 14,5 & 14,5 & 13,9 & - & $22,2(2010)$ \\
\hline
\end{tabular}

From Table 4 we can see the connection between reforms, economic development and suicide level.

Great attention should also be paid to non-communicable diseases of the population, from which the economy suffers the greatest losses at the moment. The author of the article "Economy and diseases: unfavorable prognosis" Lukyanchuk E. gives the data, according to which, according to the World Bank, it is expected that by 2030 expenditures for non-communicable diseases will be $75 \%$ of all costs associated with various diseases (including direct, indirect costs and lost profit) in the countries with the average level of income per capita.

For comparison: in 2010 this figure was estimated at $66 \%$. About $63 \%$ of deaths worldwide is the consequence of the development of these diseases. Of these, $45 \%$ of the deaths were caused by cardiovascular diseases, $21 \%$ - by malignant tumors, $12 \%$ - by chronic respiratory diseases and $3 \%$ - by diabetes.

At that, the countries with low income per capita accumulate $80 \%$ in the structure of the global costs associated with non-communicable diseases (direct treatment costs, indirect costs and lost profit). It is expected that by 2030, deaths from non-communicable diseases in the countries with average and low income per capita will increase by 50\% [15].

In this paper, the methodology for assessing the socio-economic damage and loss of time due to noncommunicable diseases and other causes is developed. Part of the results is presented below (Table 6).

Table 6: Economic damage due to lost years of productive life

\begin{tabular}{|l|c|c|c|c|c|c|}
\hline \multirow{2}{*}{ Region } & IHD & MN & APA & TA & Homicides & Suicides \\
\cline { 2 - 7 } & in \% to GRP & in \% to GRP & in \% to GRP & in \% to GRP & in \% to GRP & in \% to GRP \\
\hline Republic of Bashkortostan & 0,659 & 0,416 & 0,075 & 0,393 & 0,189 & 0,899 \\
\hline Permsky region & 0,395 & 0,456 & 0,252 & 0,467 & 0,469 & 0,873 \\
\hline Chelyabinsky region & 0,365 & 0,447 & 0,150 & 0,374 & 0,295 & 0,647 \\
\hline Irkutskaya region & 0,630 & 0,500 & 0,166 & 0,517 & 0,524 & 0,902 \\
\hline Sverdlovskaya region & 0,357 & 0,438 & 0,147 & 0,319 & 0,328 & 0,513 \\
\hline Russia (total) & 0,476 & 0,451 & 0,162 & 0,409 & 0,247 & 0,455 \\
\hline
\end{tabular}

where IHD - ischemic heart disease, MN - malignant neoplasms, APA - accidental poisoning by alcohol, TA -transport accidents.

The table shows that the economic losses of Russia from the above causes of loss of productive life constitute $2.227 \%$ of GDP.

\section{Results}

Industrial districts reach the form of advanced growth zones in the frame of development strategies hierarchy. It reflects the interaction of regional economy par.

However, various factors of losses of working time are interrelated, and - from the practical point of view - they should be compared in a single numerical scale. In our opinion, this can be done if to present them as losses of time at work.

Lwt $=\mathrm{L}_{h i d}+L_{h c d}+L_{h m d s}+\mathrm{L}_{h h o}-\mathrm{R}_{p h s},(1)$

where:

Lwt - loss of working time in the production process because of illnesses - in \% from annualized activities of workers;

$\mathrm{L}_{\text {hid }}$ - health losses because of infectious diseases \%; 
$L_{h c d}$ - health losses because of non-communicable diseases \%;

$L_{h m d s}$ - health losses because of mental disorders and suicides;

$\mathrm{L}_{h h o}$ - health losses at unhealthy work \%;

$\mathrm{R}_{p h s}-$ recovery of health of workers with the help of different measures aimed at sport and physical activity, investments in health capital.

This formula (1) can be used on the level of the region or enterprise in the process of planning and analysis of production activities for a certain period.

The importance of physical activity is well-known. Here is the general data obtained by the Federal State Statistics Service: morbidity rates of various diseases as a result of a sample survey of 2008 "Impact of behavioral factors on health of population" [11]. The relationship between physical training and the morbidity rate is clearly traced in the work. Sport activities can set equal to one of the types of "investments" into health capital.

\section{Conclusion}

Thus, the national program on the increase of availability of gyms and on motivation of population on the territory on sports activities is necessary. It will attract investment into health capital, having reduced the costs for health care and increased employment, which is particularly important for economically active population. With further increase of life expectancy of individuals, it will be possible to increase the retirement age of men and women, having reduced the deficit of the pension fund and improved not only the population but also the economy as a whole. Decrease of morbidity will positively impact the productivity and efficiency of labor and, finally, the economic security of the territory, and will allow to get out of "resource trap" with imperfect institutions.

Having analyzed the health capital as one of the strategic components of economic security at different hierarchical levels, it is necessary to say about the importance of fundamental uncertainty of the future - according to Keynes. The Russian have losses of health capital due to significant uncertainty of the future. In this case at the regional level these losses can be considered as economic losses due to lost years of productive life. At the micro level - as losses of time at work, especially because of different factors of losses of health of workers.

\section{References}

United Nations Development Programme. Human Development Reports 2014». - URL: http://hdr.undp.org/en/media/HDR2014_EN_ Summary.pdf.

Grossman M. On the concept of health capital and the demand for health // Journal of Political Economy. - 1972. - Vol. 80. Feb. P.223-255.

Rozmainsky I. V. A Simple Post Keynesian Model of Investor Myopia and Economic Growth // Montenegrin Journal of Economics. 2013. No. 9(3). P. 45-56.

The World Health Organization (WHO), World Health Statistics. - URL: http://www.who.int/whosis/whostat/RU_WHS10_Full.pdf.

The World Bank: The Worldwide Governance Indicators (WGI) project. - URL: http://info.worldbank.org/governance/wgi/.

Lvov D.S, Moiseev N.N., Grebennikov V.G. A Conception of Russia's Socioeconomic Development // Matecon, vol.32,4, 1999, M.E.Sharpe, Jnc. All rights reserved, 80 Business Park Drive, Armonk NY10504.

The World Health Organization - URL: www.who.int/mental_health/prevention/suicide/suicidepre vent/ru.

Panasyuk M., Pudovik E., Malganova I., Butov G. Régional Multicultural Community: Problems of Life Quality Estimation // Mediterranean Journal of Social Science. - Vol.5. - №8. - pp. 323-327.

Zobova I.Yu., Malganova I.G. (2014). Territorial aspects of the institutional transformation of fiscal system // Mediterranean Journal of Social Science. - Vol.5. - №8. - pp. 153-158.

Panasyuk M.V., Pudovik E.M., Malganova I.G. (2014) Modified Index Method in Scenarios of Regional Socio-Economic Development // Mediterranean Journal of Social Science. - Vol.5. - №8. - pp. 331-335.

Federal State Statistics Service. - URL: http://www.gks.ru/free_doc/2008/ demo/zdr08.htm.

Ajupov A.A Features of organization of educational process of preparation of economic profile of students based on training dealing center. Procedia - Social and Behavioral Sciences Vol. 131, pp. 97-100 // 3rd World conference on educational technology researches Turkey 07-09.11.2013.

Razumovskaya, E.M. , Kutsevol, N., Popov, M., Mishakin, T., Leto, L., Tsalikova, V. The effectiveness of management practice in the market of socially important services. Asian Social Science, Volume 10, 28 September 2014, Pages 118-122

Razumovskaya, E.M.,Lapidus, L.V., Mishakin, T.S., Popov, M.L. Features and peculiarities of the Russian passenger rail market development. Mediterranean Journal of Social Sciences vol. 5 (18 SPEC. ISSUE), pp. 165-170. 